\title{
The Differences in Using Direct Instruction (DI) Learning Strategy Based on Competitive Behavior to Civic Education Learning Achievement
}

\author{
Evi Susilawati \\ Islamic University of North Sumatera \\ Medan, Sumatera Utara, Indonesia \\ Email: evi.utnd@gmail.com \\ Harun Sitompul \\ State University of Medan \\ Medan, Indonesia \\ Julaga Situmorang \\ State University of Medan \\ Medan, Indonesia
}

Lecturer of Civic Education Study Program

Faculty of Teaching and Education Science,

\begin{abstract}
The purpose of this study was to see the difference of learning outcomes of Citizenship Education based on competitive behavior and uncompetitive using Direct Instruction learning strategy in grade VII-3 students of SMP Negeri I Labuhan Deli, Deli Serdang Regency North Sumatra Province. Population and sample were 38 students in academic year 2015/2016. Samples were taken using a saturated sampling technique. Methods of data collection in this study were obtained by using Test Results of Cognitive Learning. The data in this study were analyzed using Independent $T$-Test. The result of the research shows that the average learning outcomes of Civic Education students are taught by using direct instruction instruction that has competitive behavior $(x 1)=81,73$, while those who do not have competitive behavior $(\times 2)=93,98$. The result of hypothesis testing showed that the learning result of Civic Education of students taught by Direct Instruction learning strategy for students who have competitive behavior were higher than students who did not have competitive behavior.
\end{abstract}

Keywords: Direct Instruction Strategy, Competitive Behavior, and Civic Education Learning Achievement.

\section{INTRODUCTION}

One of the indicators of the process of learning Citizenship Education quality is the acquisition of good learning results. Factors that determine the success or failure of the learning process that can be seen from the mastery of learning strategies. Mastery of learning strategies will create quality learning and have implications for competitive, smart, and ready-to-face generation outsourcers [6]. The generation that is ready to face change means the generation that is ready to compete in the era of globalization.

The educational system must arm the next generation of millennials and generations with the skill set to be ready to compete against life in the future [18]. Therefore, competitive behavior needs to be developed in learning. Learning activities that develop competitive behaviors help students to grow selfexpression, and measure their abilities and skills. Students with competitive behavior become challenged and able to develop the potential within each of them [16]. Such competitive behavior is able to cultivate students' self-expression and they feel challenged to innovate [9]. Students who have competitive behavior are students who dare to express ideas, ideas, and ideals. Every student must have the ideals and spirit to build themselves in order to achieve his goals. That spirit can be a spirit that motivates students to compete in achieving better learning outcomes of Civic Education. The learning outcomes of Citizenship Education is the ability that students have after the students receive their learning experience.

To achieve good learning outcomes students must pass through the elements of the learning process of Civics. The learning process of Citizenship Education is interpreted as a vehicle for the establishment of identity and love of the homeland through the internalization / personalization of religious and cultural values, which underlie the following values: humanity, political values, , the value of art, economic value, and health value, which is the basic activity of human beings in order to build citizens' insight to be better, to be a whole person or berakhlaqul karimah, so that the perspective used is the internal aspect of the nation. The Citizenship Education Process has the power to change student behavior not only by internal forces but also by external forces buried in students' social environments [10]. To implement the learning process above required a learning strategy that is able to build citizens' insights for the better. Learning strategy is a learning strategy that is appropriate with the conditions in the classroom, if students are less active then they are given strategies that can make students more active, if the students' 
understanding of learning materials is not too much then they are given a teacher-centered learning strategy so that students can easily understand the material [3]. One of the teachercentered learning strategies is the direct instruction (DI) instructional strategy.

In teacher-centered learning strategies, students receive an immediate source of information from teachers [12]. DI strategy can be planned together by teachers and students [13] The advantage of using this DI strategy, the teacher can control the content of the material and the sequence of information received by the students so that students can focus on the learning objectives that must be achieved. While the weakness of DI learning strategy is the teacher difficult to overcome differences in terms of ability, initial knowledge, level of learning and understanding, learning style or student interest. The purpose of applying DI learning strategy in the subject of Citizenship Education is to improve student learning outcomes in order to understand the content and meaning contained in the Civic Education lesson. DI learning strategy applied in this research is the most appropriate learning strategy to guide students in studying Civic Education materials where the delivery of material by using demonstration and training. This allows the delivery of more optimal materials so that students are able to understand the material of Citizenship Education by implementing the practice in accordance with the material being taught. Students will be more leverage and more active and focus in learning, students experience their own learning directly so that students' understanding of the material can be measured.

Use of DI Learning Strategy makes Civic Education lessons more effective because teachers will more time to demonstrate and explain the procedures and skills of Civic Education materials. Through the phases of the DI learning model educate the students move toward independence and no longer depend on the teacher in the acquisition of knowledge. In the guiding phase of training of DI learning strategy, the teacher gives some questions to the students so that in that phase the teacher helps the students to form their own understanding of the material being studied. Students in the lesson activities are encouraged to learn by asking questions because the questions encourage students to analyze a problem (Silver, 2012: 38-40). To support the implementation of Civics learning with DI learning strategies used to make students more interested and easier to understand the material of Civics . In addition, teachers are easier in delivering information to students. With the implementation of DI learning can accelerate the absorption of students in understanding the lesson that was delivered besides it can create a varied learning, and not boring for the students (Rusman, 2012: 33).

\section{LITERATURE RVIEW}

\section{A. Direct Instruction (DI) Learning Strategy}

Basically a good learning activity should be based on the design of a good learning strategy [11]. Therefore, a good learning strategy must contain predefined learning objectives, systematic procedures using media, methods, and other tools to shape the learning experience of the students. Associated with student learning experiences, direct learning strategies emphasize student learning experiences in which students learn by imitating the successes and failures of others. Direct learning strategies are influenced by behavioristic learning theory that emphasizes more on the understanding of human behavior that has a relationship between stimulus and response. Therefore, in the implementation of DI learning strategies, the role of teachers as a stimulus is a very important factor. From this assumption, there are various concepts of how to facilitate the teacher so that the stimulus-response relationship can take place effectively.

Implementation of DI learning strategies in Civic Education learning can help students learn basic skills and acquire step-by-step knowledge. This DI learning strategy is well suited to students with basic education because the DI learning strategy is designed to promote student learning with well-structured procedural and declarative knowledge and can be taught step-by-step.

DI learning strategy is a teacher-centered learning strategy that has five steps: setting goals, explanations and / or demonstrations, practice guides, feedback, and practice extensions. Learning by using DI requires careful planning by the teacher and a fun and task-oriented learning environment. DI learning strategies provide opportunities for students to learn through observation activities, recall and imitate the behavior exemplified by the teacher. Therefore the important thing to be considered in implementing DI learning strategies is to avoid conveying knowledge that is too complex. In addition, DI learning strategies emphasize a declarative approach with emphasis on learning process concepts and motor skills, thus creating a more structured learning atmosphere.

Teachers using direct learning strategies are responsible for identifying the learning objectives, material structure, and basic skills to be taught. Then pass on knowledge to students, give demonstrations, give students the chance to practice applying learned concepts / skills, and provide feedback. The steps of DI learning strategy can be seen in Figure 1 below:

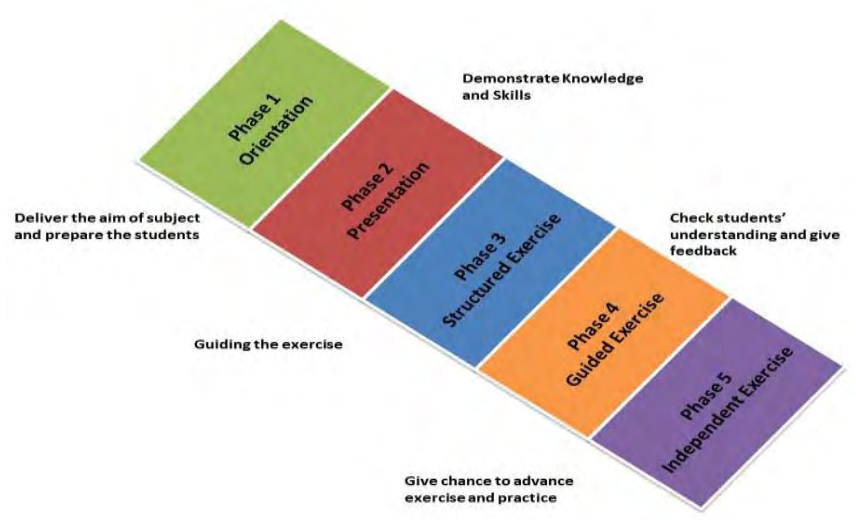

Fig. 1. Steps of DI Leatning Strategy 
The learning steps of Civic Education using the DI learning strategy in Figure 1 are described below: (1) Phase 1: EIn phase 1 this is an orientation activity with the activities undertaken by the teacher is to convey the learning objectives of Civic Education, background information, learn the material to be submitted, and prepare the students to learn; (2) Phase 2 : In phase 2 this is a presentation activity with activities undertaken by the teacher is to present information step by step; (3) Phase 3: In phase 3 this is a structured exercise activity with activities undertaken by teachers is the teacher provides guidance to students; (4) Phase 4: In phase 4 this is a guided training activity with activities undertaken by teachers is memnecek whether students have completed the task given by the teacher well; (5) Phase 5: In phase 5 this is an independent exercise activity with the activities of the teacher is giving students the opportunity to apply it to a more complex situation.

\section{B. Competitive Behavior}

Competitive behavior is defined as behavior to gain the most rewards and minimize the success on the other [17]. Competitive behavior is also defined as activities to achieve goals by beating other individuals or groups. Individuals or groups choose to work together or compete depending on the reward structure in a social interaction situation. Basically, competitive behavior is demonstrated through a competitive relationship. Competitive relationships are defined as relationships that create tension between individuals within the group, becoming a barrier to each other's individual activities, bringing negative feelings between individuals to each other, which in turn increases competition among them [19]. The development of competitive behavior in the learning activities of Citizenship Education is started because the learning of Citizenship Education that builds the competitive behavior of students is done not to gain prizes or rate increases, but to achieve higher learning outcomes, since the actual competitive behavior allowed in the learning activities of Citizenship Education must be a noble cause and no reason to forbid any competition [14].

Furthermore [1], explained that the main reason teachers develop competitive behavior is not wrong because building competitive behavior will help students learn more actively and deeper and broader learning (Chun Chen: 2017: 3178). In fact, there is no reason for teachers to prohibit competition because in a democratic lesson, it is not expected that each student achieves the same learning outcomes but different learning outcomes. Competitive behavior built in learning activities will improve student learning outcomes because: (1) when other students achieve better learning outcomes, others will learn harder to achieve better learning outcomes, (2) when students others get the idea, then the other students will think to start an idea that has been got by the friend, (3) each student will be challenged to achieve the best learning outcomes, (4) every student will always strategize to avoid failure in bell and will learn hard and not give up on fate, (5) students will be surrounded by people who build themselves with a competitive spirit [4].

\section{Civic Education Learning Achievement}

Learning is a very important human activity in human life. This happens because of the presence of other individuals who teach how other individuals live. Learning takes place inside a person and can not be seen by any other man in real terms. Therefore learning occurs through the learning process. This statement is in line with the opinion that learning is a process undertaken by human beings to obtain the various capabilities (competencies), skills (skills), and attitudes obtained gradually and sustainably from infancy to old age through a series of processes lifelong learning [7]. Learning is also interpreted as an individual change caused by experience. This can be taken in the elements of learning is the process of progress, changes in individual behavior, and experience [15].

Based on the meaning of learning can be interpreted that learning is a modification of a person's behavior through experience as measured by the results of learning. Learning outcomes are described about what activities can be performed, shown by students in terms of their knowledge, skills and attitudes after completing a learning program [5]. Referring to the meaning can be interpreted that to get good result of learning in order to change of student behavior, hence before teaching activity activity done in class, teacher should have to plan various learning experience to be given to student and experience of learning have to according to goal to be achieved. This happens also in the learning activities of Citizenship Education.

The learning outcomes of Citizenship Education are the theories and practices students have achieved in terms of citizenship issues and student relationships with fellow citizens and governments as measured by various means of learning outcomes such as through the reflection of actions, opinions, and student dedication to the nation and country, and student participation on nation and state [8]. Civic learning outcomes are also interpreted as explicit descriptions of students 'citizenship ideas, civic personality such as student inclinations or dispositions about students' knowledge and involvement in society, and the commitment students have to act on a sense of responsibility as members of society and citizens documented on the basis of certain qualifications [2]. Based on the above understanding, it can be concluded that the learning outcomes of Citizenship Education is a level of ability in students in the form of mastery of students both in the form of moral Pancasila and the 1945 Constitution, knowledge, and citizenship skills in the cognitive domain. The outcomes of Civic Education education in the cognitive domain use the test of learning outcomes in the realm of understanding, application, analysis, evaluation, and creation.

\section{RESEARCH METHODS}

The research method used in this study is the experimental method by taking two groups of samples are saturated, normal and homogeneous. This research is experimental because this research confirms a causal relationship between the variables studied. The aim is to find the facts of cause and facts due to the different DI learning strategies in Civic Education learning on student learning outcomes. With this research will be obtained a careful and objective results. The study was 
conducted by taking two groups of samples saturated in class form followed by an Independent test t-test to determine the equivalence of the class to assume that the effect of learning outcomes of Citizenship Education is really derived from the learning strategy used. Prior to the experimental activity, the first sample was given a competitive behavior questionnaire to find out the characteristics of students' competitive behavior. Furthermore, class VII-3 was given the treatment of DI learning strategies. Treatment of the study conducted for 8 weeks or 24 face to face where the subject of this Cnn one week there are 3 (three) times face to face with time 1 (one) face to face 35 minutes. The curriculum used in this research using the Curriculum 2013 (K-2013) class VII semester II (two). Prior to treatment, pretest treatment of cognitive learning outcomes was performed. Likewise after the treatment carried out the final test. The steps of implementing DI learning strategies are seen in Figure 2 below:

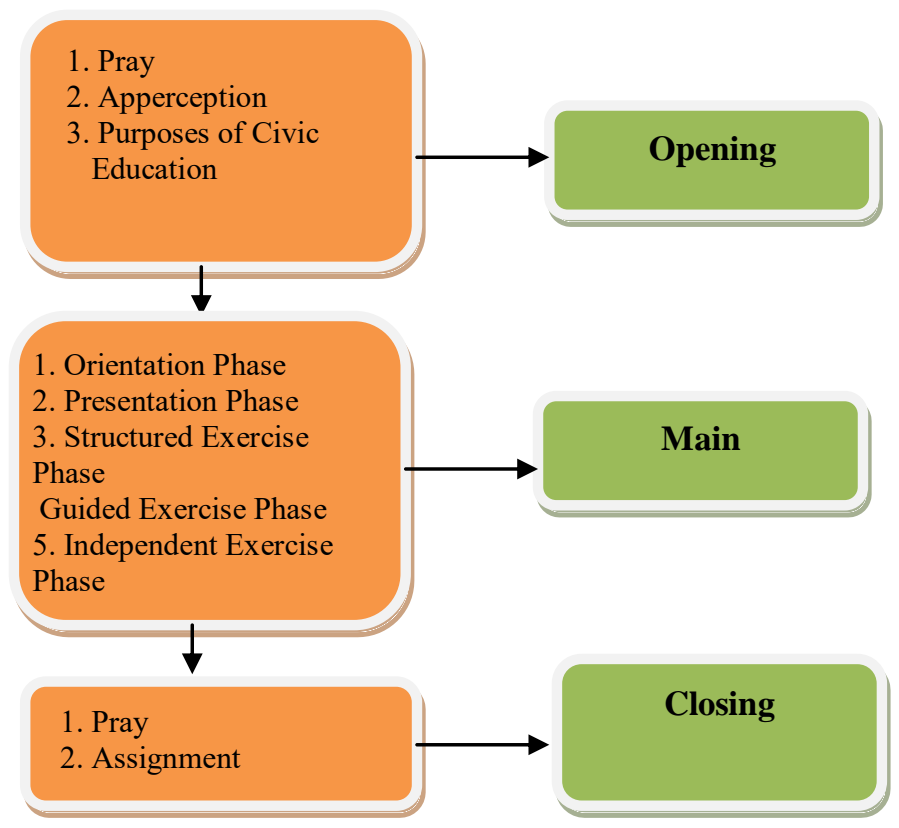

Fig. 2.Procedure of Modeling Learning Strategy Implimentation.

The steps of implementation of DI learning above is part of the design of the learning program and is the treatment instrument used as a reference in conducting the field experiment. Teachers who are given the task to implement the process of learning Civics in school SMP Negeri 1 Labuhan Deli Deli Serdang district using the above learning design as a reference in the learning process. To present the subject matter of Civics which became the scope of the study at the beginning of this study, students and teachers who received treatment followed the steps that have been designed in accordance with the constructs that have been developed.

The results of this experiment were studied and analyzed statistically parametric that fulfilled normal and homogeneous prerequisites. Data compared to the results obtained for which groups are more different from the two models of learning to student learning outcomes Education Students.

\section{RESUlT AND Discussion}

Prior to hypothesis testing, a hypothesis prerequisite test using normality testing is assumed that the data taken from the normal distributed population and the test of variant equality (homogeneity) assuming that the data taken comes from a sample with a homogeneous population. Normality test results are shown in Table 1 below:

TABLE 1. Normality Test Result

\begin{tabular}{|c|c|c|c|}
\hline \multicolumn{4}{|c|}{ One-Sample Kolmogorov-Smirnov Test } \\
\hline & & Kompetitif & $\begin{array}{c}\text { Tidak_- } \\
\text { Kompetitif }\end{array}$ \\
\hline \multicolumn{2}{|l|}{$\mathrm{N}$} & 16 & 23 \\
\hline \multirow{2}{*}{$\begin{array}{l}\text { Normal } \\
\text { Parameters }{ }^{\mathrm{a}} \text {, } \\
\text { b }\end{array}$} & Mean & 81,7308 & 93,9799 \\
\hline & $\begin{array}{l}\text { Std. } \\
\text { Deviation }\end{array}$ & 6,96851 & 4,22378 \\
\hline \multirow{3}{*}{$\begin{array}{l}\text { Most } \\
\text { Extreme } \\
\text { Differences }\end{array}$} & Absolute & 114 & 192 \\
\hline & Positive & 111 & 132 \\
\hline & Negative &,- 114 &,- 192 \\
\hline \multicolumn{2}{|c|}{ Kolmogorov-Smirnov Z } & 456 & 920 \\
\hline \multicolumn{2}{|c|}{ Asymp. Sig. (2-tailed) } & ,985 & ,366 \\
\hline
\end{tabular}

Based on Table 1 above can be seen that the results of normality test with the value of Significant Kolmogorov test on the behavior of students who have competitive behavior is 0.985 greater than 0.05 it can be concluded that the score Pkn in class VII-3 that behave competently normal distribution. Similarly, in students who have uncompetitive behavior can be seen that students who are not competitive behavior using kolmogorov test on the value Significant 0.366 greater than 0.05 then it can be said that the score of students' learning outcomes on VII-3 students who have no behavior competitive normal distribution.

Further homogeneity test results can be seen in Table 2 below:

TABLE 2. Homogeneity Test Result

\begin{tabular}{|l|l|l|l|}
\hline \multicolumn{4}{|l|}{ Test of Homogeneity of Variances } \\
\hline Skor \\
\hline $\begin{array}{l}\text { Levene } \\
\text { Statistic }\end{array}$ & df1 & df2 & Sig. \\
\hline 3,314 & 1 & 37 &, 077 \\
\hline
\end{tabular}

Referring to Table 2 it can be interpreted that based on homogeneity test results using levene test is 0.077 greater than 0.05 it can be said that both groups are homogeneous namely class VII-3 in the group of students who have competitive behavior and students who have behavior is not competitive . From the two preconditions above it can be seen that the data comes from a normally distributed population and the sample comes from the same variant, then further can be tested hypothesis using $\mathrm{T}$ independent test. $\mathrm{T}$ test results can be seen in Table 3 below: 
TABEL 3. T-Test Result

\begin{tabular}{|c|c|c|c|c|c|c|c|}
\hline \multicolumn{8}{|c|}{ Independent Samples Test } \\
\hline & \multicolumn{7}{|c|}{ t-test for Equality of Means } \\
\hline & \multirow[t]{2}{*}{$\mathrm{t}$} & \multirow[t]{2}{*}{ df } & \multirow[t]{2}{*}{$\begin{array}{l}\text { Sig. } \\
(2- \\
\text { tailed })\end{array}$} & \multirow[t]{2}{*}{$\begin{array}{l}\text { Mea } \\
\text { Diff } \\
\text { erence }\end{array}$} & \multirow{2}{*}{$\begin{array}{l}\text { Std. } \\
\text { Error } \\
\text { Diffe } \\
\text { rence }\end{array}$} & \multicolumn{2}{|c|}{$\begin{array}{l}\text { 95\% Confidence } \\
\text { Interval of the } \\
\text { Difference }\end{array}$} \\
\hline & & & & & & $\begin{array}{l}\text { Lowe } \\
\mathrm{r}\end{array}$ & Upper \\
\hline \begin{tabular}{l|l}
$\mathrm{S}$ & Equal \\
$\mathrm{k}$ & variances \\
\end{tabular} & $\begin{array}{l}-6, \\
84\end{array}$ & 37 & $\begin{array}{l}0,00 \\
0\end{array}$ & $\begin{array}{l}-12, \\
2492\end{array}$ & $\begin{array}{l}1,79 \\
18\end{array}$ & $\begin{array}{l}-15, \\
8797\end{array}$ & $\begin{array}{l}-8, \\
6186\end{array}$ \\
\hline \begin{tabular}{|l} 
Equal \\
variances \\
not \\
assumed \\
\end{tabular} & $\begin{array}{l}-6, \\
28\end{array}$ & $\begin{array}{l}22,6 \\
4\end{array}$ & $\begin{array}{l}0,00 \\
0\end{array}$ & $\begin{array}{l}-12, \\
2492\end{array}$ & $\begin{array}{l}1,95 \\
21\end{array}$ & $\begin{array}{l}-16, \\
291\end{array}$ & $\begin{array}{l}-8, \\
2074\end{array}$ \\
\hline
\end{tabular}

Based on table 3 above can be seen below the significant value (2-tailed) shows the value 0 , because 0 is smaller than 0.05 then $\mathrm{H} 0$ is rejected. Because $\mathrm{H} 0$ is rejected then $\mathrm{H} 1$ is accepted. Then it can be concluded that the students of class VII-3 taught by using DI in the group of students who behave competitively obtain better learning outcomes than students who behave uncompetitively. The results of this finding is reasonable because the implementation of learning by using DI learning strategies emphasize the influence of the exercise with the learning process takes a step-by-step so easy to identify students' learning ability. In order for the learning process to take place step by step requires a competitive behavior so that students become challenged to melatihkan knowledge they have in different social situations. Innovation of ideas and ideas is needed to become a spirit for students to compete in achieving better learning outcomes of Civic Education. Based on the results of the above research can be stated that students who have competitive behavior if taught with DI strategy will get better learning outcomes compared with students who behave uncompetitive.

\section{ACKNOWLEDGMENT}

The researchers would like to express their deep thanks to: (1) Mr. Rector of the Islamic University of North Sumatra, along with his staff, (2) Dean of the Faculty of Education and Education of Universitas Islam Sumatera Utara, along with his staff. May God Almighty provide health, well-being and repaying their good deeds.

\section{References}

[1] Ahmadi, A. \& Widodo, S. Pendidikan Bagi Anak Berkesulitan Belajar. Jakarta: Bumi Aksara. 2013.

[2] Bristol, Chantal Levesque. \& Richards, K. Andrew R. "Evaluating Civic Learning in Service Learning Programs: Creation and
Validation of the Public Affairs Scale Short Survey (PASSS)'Journal of Public Affairs Education.Vol.20 (3), 2017.

[3] Buchori, Achmad.et al. " Effectiveness of Direct Instruction Learning Strategy Assisted by Mobile Augmented Reality and Achievement Motivation on Students Cognitive Learning Results." Asian Social Science. Vol. 13, No. 9. 2017.

[4] Corell A, Regueras LM, Verdu' E, Verdu' MJ, de Castro JP "Effects of competitive learning tools on medical students: A case study". PLoS ONE. Volume 13 (3). 2018.

[5] Decklan, Kennedy. Writing and Using Learning Outcomes: a Practical Guide, Cork, University College Cork.2017.

[6] Filgona, Jacob. Filgona, Joel. Sababa, Linus K. "Mastery Learning Strategy and Learning Retention: Effects on Senior Secondary School Students' Achievement in Physical Geography in Ganye Educational Zone, Nigeria." Asian Research Journal of Arts \& Social Sciences. 2(3): 1-14, 2017.

[7] Gredler, Margaret E.. Learning and Instruction.Teori dan Aplikasi. Jakarta : Kencana Prenada Media Group. 2016.

[8] Gordon, Eric. \& Philippi, Jessica Baldin. "Playful Civic Learning: Enabling Reflection and Lateral Trust in Game-based Public Participation". International Journal of Communication, Vol.8. 2014.

[9] Hana, Urbancova. “ Competitive Advantage Achievement through Innovation and Knowledge". Journal of Competitiveness. Volume 5, Issues 1, March 2013.

[10] Kumari, Sharma. Sharma, Shapna. Jyoti. "Promoting Global Citizenship Education with Science Teaching and Analysing the Way It Is Perceived By Students at Secondary Level.” International Journal of Social Sciences. Vol. 3(3).2017.

[11] Khuana. Kwanchai, \& Khuana.Tanthip , “ Impressive Learning Strategies with Indoctrinating Research-Based to Craetive Thinking Skills for Educational Students", European Journal of Education Studies. Volume 3, Issue 2, 2017.

[12] Kumschick, Irina Rosa. Piwowar,Valentina. \& Thiel Felicitas." Inducing Adaptive Emotion Regulation by Pproviding The Students' Perspective: An Experimental Video Study With Advanced Preservice Teachers". Learning and Instruction. Volume 53. 2018.

[13] Morris, Joshua. "Instructional Discourse and Argumentative Writing”. International of Educational Reseach. 2 May 2018.

[14] Nasution, S. Didaktis Asas-Asas Mengajar. Jakarta : Bumi Aksara. 2011.

[15] Slavin, E. Robert. Psikologi Pendidikan: Teori dan Praktik. Bandung : Nusa Media. 2011.

[16] Tsiakara, Angeliki. \& Digelidis, Nikolaos M. "Assessing Preschool Children's Competitive Behaviour: An Observational System." Journal Early Child Development and Care. Volume 18. Issue 11.2014.

[17] Stangor, Charles. Social Psychology Principles. Maryland :Unnamed Publishion. 2011.

[18] Sundararajan, Arun. The Future of Work. The Digital Economy Will Sharply Orede The Traditional Employer-Employe Relationship. Wellington: A Quartelly Publication of The International Monetary Fund. 2017.

[19] Zhang, Quahwu."Social Psychologycal Consequences of Interpersonal Relation: A Comfirmatory Approach to Testing Deutch's Theory of Coorporation and Conflik Resulution". Disertation, Colombia University New York:1992. 